\title{
Paideusis
}

\section{To Carry Across: Metaphor Invents Us}

\section{Daniela Bouneva Elza}

Volume 15, Number 2, 2006

URI: https://id.erudit.org/iderudit/1072683ar

DOI: https://doi.org/10.7202/1072683ar

See table of contents

Publisher(s)

Canadian Philosophy of Education Society

ISSN

0838-4517 (print)

1916-0348 (digital)

Explore this journal

Cite this article

Elza, D. (2006). To Carry Across: Metaphor Invents Us. Paideusis, 15(2), 93-101.

https://doi.org/10.7202/1072683ar

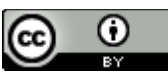

This document is protected by copyright law. Use of the services of Erudit (including reproduction) is subject to its terms and conditions, which can be viewed online.

https://apropos.erudit.org/en/users/policy-on-use/
This article is disseminated and preserved by Érudit.

Érudit is a non-profit inter-university consortium of the Université de Montréal, Université Laval, and the Université du Québec à Montréal. Its mission is to promote and disseminate research.

https://www.erudit.org/en/ 


\section{To Carry Across: Metaphor Invents Us}

DANIELA BOUNEVA ELZA

Simon Fraser University, Canada

"Our daily speech continually fluctuates between the ideals of mathematical and imaginative harmony."

Lev Vygotsky (1962)

"The real discovery is the one that will let philosophy resume thinking metaphorically when it needs to."

Jan Zwicky (2003) 
"...philosophy either recognizes or invents the different categories of being in the world while metaphors feed on the violations of such categorical distinctions."

Graver \& Lee (1994)

\section{semantic anomaly}

(this way ideas

take form

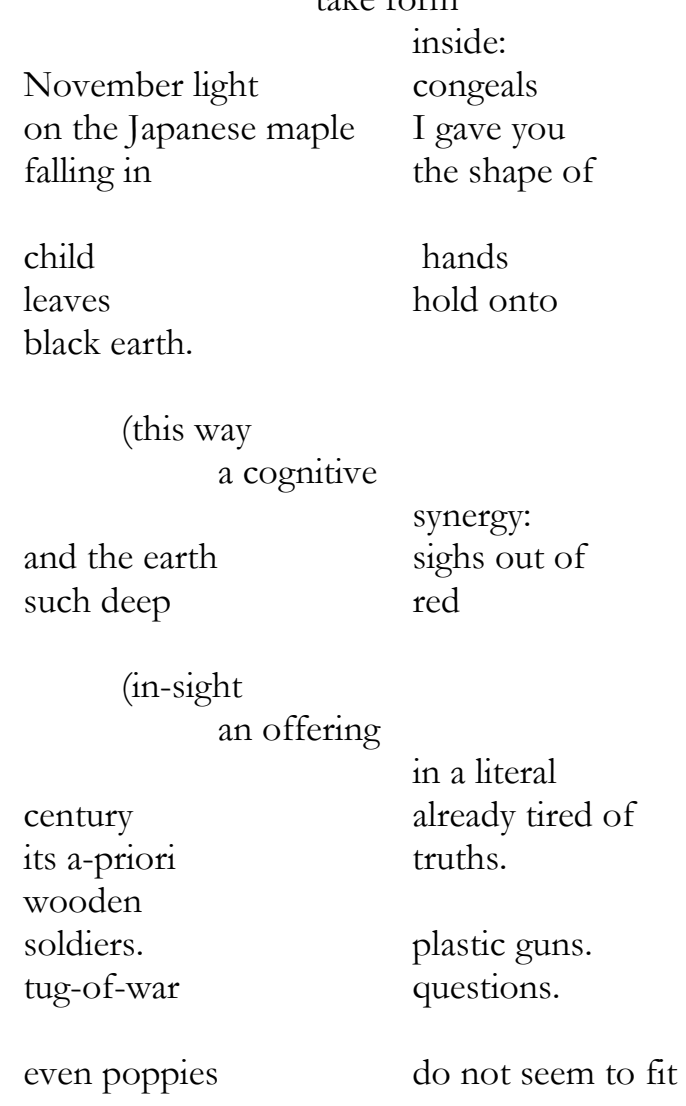

this sorrow.

(leaving me

$\begin{array}{ll}\begin{array}{l}\text { words- } \\ \text { turning in the pit }\end{array} & \begin{array}{l}\text { lumps in the throat } \\ \text { of the stomach }\end{array} \\ \text { and still surfacing } & \begin{array}{l}\text { as pure beams } \\ \text { of light }\end{array} \\ \text { curled up } & \\ \text { inside little fists. }\end{array}$


"We feel like what we see like." Ricoeur (1978)

"Feeling is not contrary to thought. It is thought made ours." Ricoeur (1978)

"The unity of a poem is the unity of a mood." Northrop Frye (Ricoeur, 1978)

\section{feeling is believing}

Ricoeur tells us:

feeling is thought
the sublimating effect of
a body of words
we share icons
textures
that could be muddled by
or the way
into itself.

made ours

inhabiting

where

verbal

of thought

an afternoon rain

a wing gathers

Frye believes:

the unity of a poem is

the unity of a mood

already the mention

of an egret

in water

is a way of touching

what cannot be

named

a way of carrying

across

what resonates

with the compelling voice of

the image

its clarity. 
"Bachelard will ask not what is imagination? What is an image? He would ask, however, what is our comprehension of images?"

Bachelard (1988)

"Bachelard invites us to experience the essential mobility of concepts."

Bachelard (1988)

"To know is to use a metaphor."

M. Friquegnon

\title{
a possible explanation (or of knowing
}

\author{
the front part of a crow comes into \\ the picture: a grad.ual emergence \\ there are no trees here among \\ an it.eration of meta pieces \\ the snowflake is. (un.spoken. \\ this place could be as dry as sawdust \\ or as full as a savannah rain \\ to know is to use a metaphor. \\ weave a cocoon of (a possible explanation. \\ to escape the fire of the half blade. \\ here \\ half a woman will serve you half \\ a bread on half a scarf \\ the other half exists in a place \\ of (seeing as
}

where blades are another way of imagining ourselves bowing in a wind of steel.

in the slow fluidity of redefining

only the numbers here are (whole

and when you turn your head

after the crow (you may see it

leaving (with your one eye. 
"Laughter is the sound of sudden knowledge."

"We get our authority from authenticity."

"The story itself pulls us because we are fascinated by the way time can unfold itself the end finally revealed as present in the beginning."

Weinberger (2002)

\title{
small metaphors loosely joined
}

\author{
laughter is the sound of $\quad$ (sudden knowledge) \\ a proximity \\ (an intimacy) \\ where walls are just \\ (rain) \\ we walk through \\ and are absorbed \\ in the poetic of language. \\ the reader is grounded in \\ what is built out of another's words. \\ we get our authority from authenticity \\ placed just so that we are (closer \\ to the sound of our own knowing \\ to our- selves \\ (words mere vehicles) resonating \\ the story itself pulls us
}

through it's narrow streets cracked

windows creaking stairways

because we are fascinated by the way

the buildings look with their green copper roofs

time can unfold itself

in front of the bakery the old sign

in the Beginning

the end finally revealed as Present

the smell of the brick oven waking me up

in my grandmother's house. 
"The way we see fire tells more about ourselves than the external world"

Bachelard (1988)

"...nothing can be seen of the soul but it sees everything"

Levchev (2006)

"Fire is more likely to smolder beneath the soul than beneath ashes."

Bachelard (1988)

\section{saying is}

\section{(seeing as}

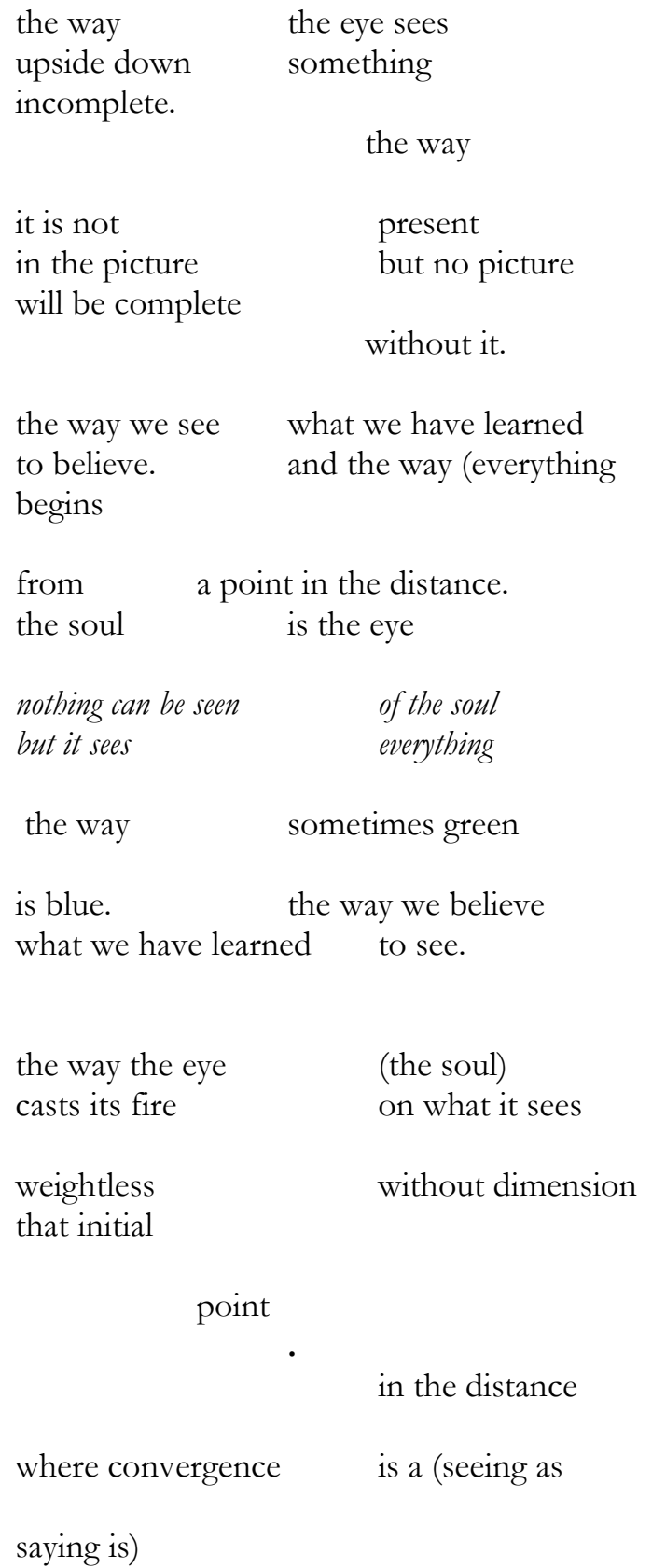


"In Nietzsche metaphor builds the bridge between morality and immorality." Parker (1982)

"Each new poetic world is not a pure invention, it is a possibility in nature."

Bachelard (1988)

\title{
bridging distances (or of metaphor
}

\author{
the fear of falling (is) distances \\ lack of bridges (over) old spaces \\ that yawn (the need) to be occupied. \\ crumbling brick (marks on \\ the peeled façade) of warehoused ruin \\ words (the witness of decay) \\ the river sweeps away distances \\ (under bridges.) \\ the fear of falling is turning us \\ into rain \\ and rain re-turns \\ memory to water. \\ this twilight curled up \\ inside words \\ where \\ (suddenly) \\ distances become bridges over old spaces \\ and clouds shift-shape our destinies \\ to purposes we do not remember \\ dreaming of. \\ (the fear of falling) is turning us \\ into something else.
}


"The kinds of phenomena and experience we address in our disparate fields are intrinsically extradisciplinary - they require diverse perspectives, a broad range of illuminating discourse."

Nabhan (2004)

\section{cross pollination in translation}

\author{
knowledge \\ scientific \\ (Butterflies \\ Ponds \\ Trash \\ Peacocks
}

indigenous poetic

and ecological

knowledge

in between

words

Confusing with moths

with nectar pods)

with washed organic detritus

(with macaws.)

To translate moths as

night

butterflies

is to

obscure

the meaning

of the song.

$\begin{array}{ll}\begin{array}{l}\text { when things are } \\ \text { by words }\end{array} & \text { held together } \\ \text { like that } & \begin{array}{l}\text { an imprecision } \\ \text { is a break in }\end{array} \\ \text { the woven } & \text { web. }\end{array}$




\section{References}

Bachelard, G. (1988). On poetic imagination and reverie: Selections from Gaston Bachelard. Dallas, TX: Spring Publications.

Cahnmann, M. (2003). The craft, practice, and possibility of poetry in educational research. Educational Researcher, 33 (3), 29-36.

Campbell, J. (1986). The inner reaches of outer space: Metaphor as myth and religion. New York: Harper \& Row. Garver, N. \& Lee, S. (1994). Derrida \& Wittgenstein. Philadelphia: Temple University Press.

Levchev, L. (2006). Ashes of light: New and selected poems. Willimantic, CT: Curbstone Press.

Nabhan, G. P. (2004). Cross-pollination: The marriage of science and poetry. Minneapolis, MN: Milkweed Editions.

Parker, P. A. (1982). The metaphorical plot. In D. S. Miall (Ed.), Metaphor: Problem and perspectives (pp. 133-157). Sussex, England: Harvester Press.

Postman, N. (1995). The end of education: Redefining the value of schools. New York: Vintage Books.

Ricoeur, P. (1978). The metaphorical process as cognition, imagination, and feeling. Critical Inquiry, 5 (1), 143-159.

Simms, K. (2003). Paul Ricoeur. London: Routledge.

Vygotsky, L. S. (1962). Thought and language. (E. Hanfmann \& G. Vakar, Trans. and Eds.). Massachusetts: M.I.T. Press.

Weinberger, D. (2002). Small pieces loosely joined: A unified theory of the web. Massachusetts: Perseus. Zwicky, J. (2003). Wisdom and Metaphor. Kentville, NS: Gaspereau Press.

\section{About the Author}

Daniela Bouneva Elza is a Ph. D. student in the Faculty of Education at Simon Fraser University. Having lived on three continents and crossed numerous geographic and cultural borders, Daniela is a semantic anomaly herself, a rogue scholar at heart. Her research interests are in creativity, imagination, bridging the theory-practice divide, alternative methods of inquiry, and more specifically in metaphor and how metaphor shapes our knowing. Currently she is working on two collections of poems. She can be reached at daniela@livingcode.org. 